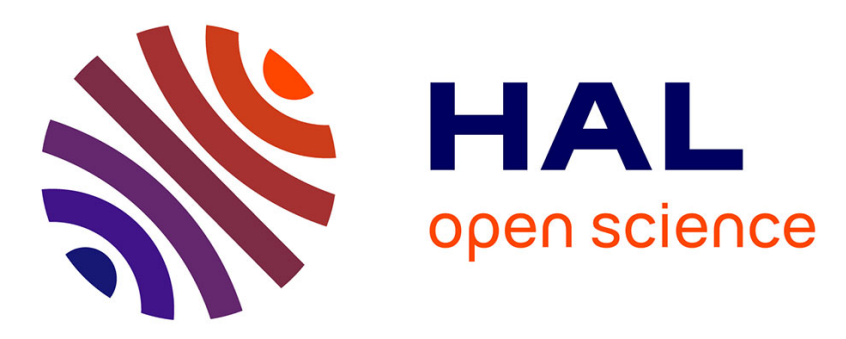

\title{
Speciation and quantitation of precious metals in model acidic leach liquors, theoretical and practical aspects of recycling
}

Jéremie Gouyon, Fanny d'Orlyé, Julia Zimmerman, Sophie Griveau, Fethi Bedioui, Anne Varenne

\section{To cite this version:}

Jéremie Gouyon, Fanny d'Orlyé, Julia Zimmerman, Sophie Griveau, Fethi Bedioui, et al.. Speciation and quantitation of precious metals in model acidic leach liquors, theoretical and practical aspects of recycling. Analytical and Bioanalytical Chemistry, 2020, 10.1007/s00216-020-02707-4 . hal-03021330

\section{HAL Id: hal-03021330 \\ https://hal.science/hal-03021330}

Submitted on 24 Nov 2020

HAL is a multi-disciplinary open access archive for the deposit and dissemination of scientific research documents, whether they are published or not. The documents may come from teaching and research institutions in France or abroad, or from public or private research centers.
L'archive ouverte pluridisciplinaire HAL, est destinée au dépôt et à la diffusion de documents scientifiques de niveau recherche, publiés ou non, émanant des établissements d'enseignement et de recherche français ou étrangers, des laboratoires publics ou privés. 


\author{
Jéremie Gouyon ${ }^{1,2}$, Fanny d'Orlyé ${ }^{1}$, Julia Zimmerman ${ }^{1,3}$, Sophie Griveau ${ }^{1}$, Fethi Bedioui ${ }^{1}$, Anne Varenne ${ }^{1}$
}

4

${ }^{1}$ Chimie ParisTech, PSL University, CNRS 2027, Institute of Chemistry for Life and Health Sciences, SEISAD 75005 Paris,

France.

${ }^{2}$ French Environment and Energy Management Agency, 20, avenue du Grésillé- BP 9040649004 Angers Cedex 01 France

${ }^{3}$ Instituto Militar de Engenharia, Rio de Janeiro, Brazil

E-mail: anne.varenne@ chimieparistech.psl.eu (Varenne A.)

\title{
10 Abstract
}

11 Waste printed circuits boards are a major source of strategic materials such as platinum group metals since they are used for the fabrication of technological devices, such as hard drive discs, capacitors, diodes, etc. Because of the high

13 cost of platinum, palladium and gold $(>25 \mathrm{k} € / \mathrm{kg})$, an economic and environmental challenge is their recycling from

14 printed circuit boards, that represent around 2\% weight of electronic equipment. Hydrometallurgical treatments allow

15 to recover these metals in solution, with a high recovery rate for a leaching liquor made of thiourea in hydrochloric

16 acid. So as to develop an efficient recycling process from this leach liquor, one requires the speciation of these

17 strategic metals, as well as their extraction and quantitation in the mixture. For this purpose, platinum, palladium and

18 gold were dissolved in model leach liquors made of hydrochloric acid and thiourea at low concentration. The

19 identification of metal complexes was determined in function of thiourea concentration (between $10 \mu \mathrm{mol} / \mathrm{L}$ and 10

$20 \mathrm{mmol} / \mathrm{L}$ ) by the combination of UV-Visible spectrometry, cyclic voltammetry and for the first time capillary

21 electrophoresis. The electrokinetic method was then applied for the quantitation of trace metal analyses in leach

22 samples from waste printed circuit boards reprocessing, demonstrating its applicability for industrializable recycling

23 applications. 


\section{Keywords}

25 Strategic metals -Thiourea - UV spectrophotometry - Voltammetry - Electrophoresis

\section{Declarations}

27 Not Applicable 


\section{Introduction}

29 The Electrical and Electronic Equipment (EEE) are more and more common in our daily life, and their production is

30 still increasing since the past decades. Computers, smartphones or televisions represent a major source of diverse materials such as strategic ones, as they turn to become waste (WEEE, Waste Electrical and Electronic Equipment). Those materials are defined by the European Commission [1] as species with supply risks and of high economic issue. Particularly, the Printed Circuits Boards (PCBs) - that compose almost 2\% weight of the WEEE [2] - contain a high diversity of strategic materials, like platinum group metals (PGM) or rare earth elements. These elements that are mostly produced in South Africa and in Russia [3] are present in relatively low content $(<1 \%$ weight $)$ but represent a high added value that needs to be valorized because of their nature (Fig. S1).

Particularly, platinum (Pt) and palladium (Pd) are used in the fabrication process of hard drive discs, capacitors, diodes, etc. Pt and Pd recovery is even more interesting due to their high cost ( $>25 \mathrm{k} €$ per kilogram in 2018) [4]. Gold $(\mathrm{Au})$, which is not currently considered as critical raw material, is also interesting to collect because it represents the most recoverable metallic species in PCBs. It has to be taken into account that the spatial and temporal origin of a PCBs is of importance, due to the fact that the EEE are becoming more and more efficient since the last decades and tend to contain more and more critical materials.

The recycling process of the waste PCBs is an important step for the recovery of these metals, and goes through different steps described in the literature that can be summarized as follows [5] : (i) a mechanical treatment to split different categories of materials (plastics, ferrous and non-ferrous metals), (ii) pyrolysis technics to remove plastics that remain in order to obtain a metallic powder, and (iii) hydrometallurgical treatments to dissolve the metals (selectively or not) by leaching. There exists a lot of different media to perform the leaching of Pt, $\mathrm{Pd}$ and $\mathrm{Au}$, such metallic compounds vary from one method to another (Table S1). such as $\mathrm{Au}$ and Pd. With an efficiency that can reach $100 \%$, the use of concentrated aqueous $\mathrm{HCl}$ solution (from 0.1 to $5 \mathrm{~mol} / \mathrm{L}$ ) containing $\mathrm{Cl}_{2}, \mathrm{H}_{2} \mathrm{O}_{2}$ or $\mathrm{NaClO}_{4}$ is useful to selectively remove precious metals from waste PCBs, even 
if other metallic species such as copper are noticed to be also leached and thus interfering in the recycling process. But this treatment in general doesn't stop at this point. Subsequent purification steps can be involved.

The leach liquor is treated to be cleaned from what can be considered as lowering the performances of the process (such as other ions, plastics, etc...). In the case of waste PCBs, and due to its mean composition, copper and other common metals like iron and tin can also be found in the leach liquor. Several methods were developed for the purification of PCBs leach liquor, such as liquid-liquid extraction [6], the use of exchange resin [7], precipitation [8]

60 and cementation [9]. The chemical modification of resin with thiourea has shown great results concerning the retention of some of the above cited species. Indeed, thiourea has been used for the modification of different support, such as magnetic nanoparticles [10] or chitosan [11] and shows strong interaction with precious metal ions. Thiourea is also used for the elution of these species from some commercial resins dedicated to the specific retention of precious metals in acidic media [12], forming new complexes in concentrated and purified solution. The purification process with thiourea-based sorbent or by elution containing thiourea is thus promising and of interest for the specific recovery of PGM, since it allows a good selectivity. In this context, the speciation of these metals in leach liquors is of interest to fully understand their behaviour, to optimize the hydrometallurgical treatment and the recovery process.

For now, some studies focused on precious metals complexation with thiourea, showing a different behavior of each metal in acidic media (sulfuric acid, $\mathrm{HCl}$ and nitric acid). For example, $\mathrm{Au}(\mathrm{III})$ is spontaneously reduced to its $\mathrm{Au}(\mathrm{I})$ form, interacting with thiourea in excess to form one single complex of $\mathrm{Au}(\text { thiourea })_{2}{ }^{+}$[13]. In the case of $\mathrm{Pd}$, chloride ions from $\mathrm{PdCl}_{4}{ }^{2-}$ can be replaced by thiourea, to form consequently $\mathrm{Pd}(\text { thiourea })_{4}{ }^{2+}$, with intermediates such as, $\mathrm{PdCl}_{2}$ (thiourea $)_{2}$ and $\mathrm{Pd}_{2}(\text { thiourea })_{2} \mathrm{Cl}_{4}[14,15]$. For the $\mathrm{Pt}$ ion, the rare studies devoted to the analysis of the exact mechanism of complexation with thiourea assume that $\mathrm{Pt}(\mathrm{IV})$ is reduced to $\mathrm{Pt}(\mathrm{II})$ to form $\mathrm{Pt}\left(\right.$ thiourea ${ }_{4}{ }_{4}^{2+}$, or to form dimer complexes [16].

In order to complete the knowledge about the speciation of Pt, $\mathrm{Pd}$ and $\mathrm{Au}$ ions in acidic solution in terms of complexation and oxidation states, UV-visible spectrophotometry, capillary electrophoresis (CE) and voltammetry have been used for the analysis of these metal ions in artificial leach liquor, in the absence or presence of thiourea at different concentrations, and the understanding of interaction mechanisms is discussed. The performance of capillary electrophoresis for thiourea-complexes detection and quantitation is then demonstrated by analysing real leach 
liquors, spiked with known quantities of precious metals and pretreated on solid phase extractant dedicated to the specific recovery of platinum group metals and precious metals ( $\mathrm{Pt}, \mathrm{Pd}, \mathrm{Au} . .$.$) .$

83

\section{Material and Methods}

\section{Reagent}

The artificial leach liquors were made by dilution of appropriate amounts of standard solution of Gold Standard for ICP TraceCERT ${ }^{\circledR} 1000$ mg/L (5\% HCl, Sigma-Aldrich co. LCC., Paris, France), Palladium Standard for ICP TraceCERT ${ }^{\circledR} 10000$ mg/L and Platinum Standard for ICP TraceCERT® 10000 mg/L (10\% HCl with HNO3- traces, Sigma-Aldrich co. LCC, Paris, France) in $1 \mathrm{~mol} / \mathrm{L} \mathrm{HCl}$ (made from $\mathrm{HCl}$ for analysis 37\%. Acros Organics, Geel, Belgium) and Ultrapure water. $\mathrm{CuCl}_{2}(99 \%)$, Thiourea (ACS reagent, $\left.\geq 99.0 \%\right)$ and $\mathrm{NaCl}(\mathrm{BioXtra} . \geq 99.5 \%$ ) were provided by Sigma-Aldrich (Paris, France).

\section{$U V$-Visible spectrophotometry}

UV/Vis absorption spectra were acquired on a Lambda 750 UV/Vis/NIR Spectrophotometer (PerkinElmer Inc., Shelton, USA). The analyses were performed between 200 and $800 \mathrm{~nm}$ in a quartz cell. The solutions were diluted 50 times in $0.1 \mathrm{~mol} / \mathrm{L} \mathrm{HCl}$ prior to analysis to avoid signal saturation. $0.1 \mathrm{~mol} / \mathrm{L} \mathrm{HCl}$ was used as a blank solution.

\section{Capillary electrophoresis}

CE experiments were performed on an HP3DCE capillary electrophoresis system (Agilent Technologies. Waldbronn, Germany). The fused silica capillary dimensions (from Polymicro Technologies. Phoenix. AZ. USA) were $35 \mathrm{~cm}$ length, $50 \mu \mathrm{m}$ intern diameter, with a detection window at $26.5 \mathrm{~cm}$. The capillary activation was performed by flushing the capillary with $1 \mathrm{~mol} / \mathrm{L} \mathrm{NaOH}$ and $0.1 \mathrm{~mol} / \mathrm{L} \mathrm{NaOH}$ for $10 \mathrm{~min}$, rinsed with water for 10 min, with $0.1 \mathrm{~mol} / \mathrm{L} \mathrm{HCl}$ for $5 \mathrm{~min}$ and rinsed a second time with water for $5 \mathrm{~min}$ prior to analysis. The background electrolyte (BGE) was daily prepared, made of $1 \mathrm{mmol} / \mathrm{L} \mathrm{HCl}$ and $50 \mathrm{mmol} / \mathrm{L} \mathrm{NaCl}$, without or with addition of thiourea ( $2 \mathrm{mmol} / \mathrm{L})$ according to cases. Successive injections of sample and BGE were performed under $30 \mathrm{mbar}$ for $2 \mathrm{~s}$. The separation conditions were as follows: $-11 \mathrm{kV}$ for anions separation, $+11 \mathrm{kV}$ for cations separation; the diode array detector was used at different wavelengths. The temperature was maintained at $25^{\circ} \mathrm{C}$ for every experiment. 
107 Cyclic and linear hydrodynamic voltammetry (CV and LHV) were performed in a classical three-electrode system 108 cell, composed of glassy carbon (OrigaTip - Glassy Carbon Tip 3mm diameter, Origalys, Rillieux-la-Pape, France) used as working electrode (WE), a platinum wire as counter electrode (CE) and a Saturated Calomel Electrode (SCE,

110 Radiometer Analytical) as reference electrode (RE). The acquisitions were performed with a Model 263A

111 Potentiostat/Galvanostat (Princeton Applied Research, Oak Ridge, USA), coupled with the Powersuite software.

112 LHV with rotating electrode at $1000 \mathrm{rpm}$ were driven by an OrigaTrod Rotating Disk Electrode instrument

113 (Origalys, Rillieux-la-Pape, France). All experiments were performed at room temperature $\left(\mathrm{T}=23 \pm 2^{\circ} \mathrm{C}\right)$.

114

115

\section{Leach liquor preparation and treatment}

The preparation and process of PCBs leach liquor, either non spiked or spiked with a mixture of Pd and Au, at 10 $\mathrm{mg} / \mathrm{L}$ each (named LL and LLsp, respectively) is described in fig. S2 and can be summarized as follow: $30 \mathrm{~g}$ of crushed waste PCBs $(<750 \mu \mathrm{m})$ [17] were immersed in $300 \mathrm{~mL}$ of a $1 \mathrm{~mol} / \mathrm{L} \mathrm{HCl}$ solution and $1.8 \mathrm{~mL}$ of a $30 \%$ $\mathrm{H}_{2} \mathrm{O}_{2}$. (w/v, in water). The mixture was stirred at $500 \mathrm{rpm}$ for $24 \mathrm{~h}$ prior to filtration on Whatman paper to remove particles. The filtered leach solution (referred to as solution $\mathrm{LL}_{\mathrm{A}}$ ) was then treated on a solid phase extraction cartridge (Analig® PM 07, GLSciences, Tokyo, Japan) [18-20] according to the following procedure: the cartridge was conditioned with $25 \mathrm{~mL}$ of a $1 \mathrm{~mol} / \mathrm{L} \mathrm{HCl}$ solution before loading $25 \mathrm{~mL}$ of $\mathrm{LL}_{\mathrm{A}}$. The sample matrix discarded through the loading step is called solution $\mathrm{LL}_{\mathrm{B}}$. The cartridge was then rinsed with $25 \mathrm{~mL}$ of a $1 \mathrm{~mol} / \mathrm{L} \mathrm{HCl}$ solution. Eventually, target analytes were desorbed and collected as three independent fractions referred to as solutions $\mathrm{LL}_{\mathrm{Cl}}$, $\mathrm{LL}_{\mathrm{C} 2}$ and $\mathrm{LL}_{\mathrm{C} 3}$ respectively) originating from three successive elutions with $3.75 \mathrm{~mL}$ of a $0.5 \mathrm{~mol} / \mathrm{L}$ thiourea solution in $0.1 \mathrm{~mol} / \mathrm{L} \mathrm{HCl}$. Rinsing and elution steps were performed at a constant flow rate of $1 \mathrm{~mL} / \mathrm{min}$ by applying a negative pressure with a peristaltic pump at the cartridge outlet. For controls, a $1 \mathrm{~mol} / \mathrm{L} \mathrm{HCl}$ solution, either pure or spiked with Pd and/or Au standard solutions (referred to as $\mathrm{HCl}$ and HClsp, respectively) and LLsp spiked with the same standard solutions to give a final concentration of $10 \mathrm{mg} / \mathrm{L}$ each were submitted to the same extraction process.

\section{Results and discussion}

In the present study, the different metallic ions ( $\mathrm{Pd}, \mathrm{Pt}$ and $\mathrm{Au}$ ) are diluted in artificial acidic leach liquors, composed of $\mathrm{HCl}$ (concentration up to $0.1 \mathrm{~mol} / \mathrm{L}$ ) and thiourea, (concentration up to $10 \mathrm{mmol} / \mathrm{L}$ ) at $\mathrm{pH}=1$. They are assumed 

and $\log \mathrm{K}=29.6$ for chloride with $\mathrm{Au}(\mathrm{III})$ [21] and 5.76 for thiourea with $\mathrm{Au}(\mathrm{I})$ [22]). Furthermore, they can exist under different forms, according to their oxidation state. So as to study the speciation of $\mathrm{Pd}, \mathrm{Pt}$ and $\mathrm{Au}$ in this leach liquor, three analytical methods were employed: (i) UV spectrophotometry, that gives information about optical properties of complexes in solution, and indicates the presence or the absence of a peculiar complex (ii) $\mathrm{CV}$ and LHV to characterize the electrochemical activity of the metallic species, that is known to depend on its complex form and influenced by the nature of the ligand and (iii) CE which can evidence a mobility shift of the metallic species according to their global charge density and hydrodynamic radius, i.e. to their complexation and oxidation states.

$142 \quad U$ V-Visible spectrophotometry

143 A diluted solution of $\mathrm{Pd}(20 \mu \mathrm{mol} / \mathrm{L}$ in $\mathrm{HCl} 0.1 \mathrm{~mol} / \mathrm{L})$, mimicking an artificial leach liquor, was studied by UVvisible absorption spectrophotometry in order to determine its optical properties and its complexation state (Fig.1 and Table 1). The spectrum of Pd (straight line) shows two absorption peaks at $222 \mathrm{~nm}\left(24650 \mathrm{~L} \cdot \mathrm{mol}^{-1} . \mathrm{cm}^{-1}\right) \mathrm{and}_{278 \mathrm{~nm}}$ $\left(8370 \mathrm{~L} \cdot \mathrm{mol}^{-1} . \mathrm{cm}^{-1}\right)$, with almost no variability after one-week storage at $+4^{\circ} \mathrm{C}(<10 \%)$. According to the literature [23], soluble Pd ion can exist in chloride media under two different oxidation state of + II or + IV. It has been demonstrated by UV-Visible spectrophotometry that the chlorocomplexes remain in acidic media under a planar tetrachlorocomplex $\mathrm{PdCl}_{4}{ }^{2-}(+\mathrm{II})$, and/or an octahedral complex $\mathrm{PdCl}_{6}{ }^{2-}(+\mathrm{IV})$. The latter can be obtained in strong oxidative conditions [24], but is generally not observed in mild conditions. Our results are in good agreements with previous work [25], with a ratio $\varepsilon_{222 \mathrm{~nm}} / \varepsilon_{278 \mathrm{~nm}}=2.95$ (versus 3.00 for $9.4 \mu \mathrm{mol} / \mathrm{L} \mathrm{Pd}$ in $0.1 \mathrm{~mol} / \mathrm{L} \mathrm{HCl}$ in the literature), demonstrating that $\mathrm{PdCl}_{4}{ }^{2-}$ remains the main complex in a solution at low $\mathrm{pH}$ and high chloride content, and is quite stable.

The addition of thiourea at different Pd:thiourea ratios (1:1 to 1:10) induces an evolution in the optical properties of the solution, supported by visual observation. For ratios lower than 1:1; a red-brown precipitate appears. Further addition of thiourea leads to an intense red coloration of the solution, that turns to a yellow clear coloration at ratio 1:4 (tile curve), characterized by an absorption peak at $\lambda=246 \mathrm{~nm}\left(30255 \mathrm{~L} . \mathrm{mol}^{-1} . \mathrm{cm}^{-1}\right.$, Fig. 1). Higher ratio does not lead to any further visible modification of the solution, but shows a strong increase in the UV absorption at a wavelength of $236 \mathrm{~nm}$. The addition of thiourea in the media has been previously studied [26]. Three different ratios 

good agreement with the literature, with a red-brown precipitate for ratio lower than 1:1 attributed to the formation of the dimer of $\left.\left[\mathrm{Pd}(\text { thiourea }) \mathrm{Cl}_{2}\right]_{2}\right)$ [27]. The intense red color that appears between ratio $1: 1$ and $1: 4$ is attributed to $\operatorname{Pd}(\text { thiourea })_{2} \mathrm{Cl}_{2}$, slowly leading to the formation of $\mathrm{Pd}$ (thiourea) ${ }_{4}{ }^{2+}$ for higher thiourea content. This latter complex has been studied and characterized, showing its stability in this medium [26, 28]. A speciation diagram is presented in Fig. S3 and is discussed below.

\section{Capillary electrophoresis}

The analysis of Pd artificial leach liquor (1 mmol/L Pd in $\mathrm{HCl} 0.1 \mathrm{~mol} / \mathrm{L}$ ) by CE (Fig. 2.a) presents a single peak at a negative electrophoretic mobility $\left(1, \mu_{\mathrm{ep}}=-51.3 \pm 0.3 \cdot 10^{-5} \mathrm{~cm}^{2} \cdot \mathrm{V}^{-1} \cdot \mathrm{s}^{-1}\right)$ at both 222 and 270 nm wavelengths, with a ratio $\varepsilon_{222 \mathrm{~nm}} / \varepsilon_{270 \mathrm{~nm}}=3.95$. Moreover, three minor peaks (2) are visible at a migration time lower than 2 min, one of them being attributed to $\mathrm{NO}_{3}{ }^{-}$, originating from the standard $\mathrm{Pd}$ solution. This result tends to prove the existence of $\mathrm{Pd}$ ion at $+\mathrm{II}$, forming the $\mathrm{PdCl}_{4}{ }^{2-}$ complex characterized by a ratio $\varepsilon_{222 \mathrm{~nm}} / \varepsilon_{270 \mathrm{~nm}}$ of 3.34 (obtained by a standard UV analysis by spectrophotometry). The difference in molar extinction coefficient ratio between CE and UV can be attributed to the fact that $\mathrm{CE}$ gives access to a separative dimension, contrary to spectrophotometry that analyzes the entire sample. Indeed, impurities such as nitrate ions have been identified here by CE at traces amount (Fig. 2.a). Another explanation concerning the difference in this ratio can arise from the possible equilibrium between $\mathrm{PdCl}_{4}{ }^{2-}$ and $\mathrm{PdCl}_{3}{ }^{-}$.

Indeed, the sample is diluted in concentrated $\mathrm{HCl}(1 \mathrm{~mol} / \mathrm{L})$, whereas the $\mathrm{BGE}$ used for $\mathrm{CE}$ is composed of sodium chloride and lower amount of $\mathrm{HCl}(\mathrm{NaCl} 50 \mathrm{mmol} / \mathrm{L}$ and $\mathrm{HCl} 1 \mathrm{mmol} / \mathrm{L}) . \mathrm{Pd}$ ion mobility is highly dependent on the chloride concentration of the BGE [29], the less is the chloride amount, the less is the electrophoretic mobility of the $\mathrm{Pd}$ complex, characteristic of the dissociation of $\mathrm{PdCl}_{4}{ }^{2-}$ into $\mathrm{PdCl}_{3}{ }^{-}$. The optical properties of these two complexes are different [30], explaining why the ratio $\varepsilon_{222 \mathrm{~nm}} / \varepsilon_{270 \mathrm{~nm}}$ can be different from the one obtained by UV spectrophotometry.

Addition of thiourea in the sample leads to a drastic modification in peak electrophoretic mobility. The injection of a solution of Pd:thiourea ratio 1:4 in the BGE, void of thiourea, doesn't show any visible signal in negative polarity $(-11 \mathrm{kV})$. The inversion of polarity $(+11 \mathrm{kV})$ leads to an asymmetric peak (Fig. 2.b, dashed line) at $246 \mathrm{~nm}$, and a second very broad one. The addition of thiourea $(2 \mathrm{mmol} / \mathrm{L})$ in the BGE leads to a single peak in positive polarity at 
$246 \mathrm{~nm}$ (Fig. 2.b straight line, $\mu \mathrm{ep}=+34.1 \pm 0.210^{-5} \mathrm{~cm}^{2} \cdot \mathrm{V}^{-1} \cdot \mathrm{s}^{-1}$ ), with a ratio $\varepsilon_{246 \mathrm{~nm}} / \varepsilon_{270 \mathrm{~nm}}=1.36$. CE analysis corroborates the formation of $\operatorname{Pd}(\text { thiourea })_{4}{ }^{2+}$ at high thiourea concentration. Indeed, the hypothesis that the charge of the complex shifts from -2 to +2 should lead to an inversion of the migration direction of the complex under an electric field, especially under low electroosmotic mobility as it is the case in the considered BGE of low pH. When Pd sample is prepared in the BGE containing thiourea, and separated in a BGE void of thiourea, its complexed form $\operatorname{Pd}(\text { thiourea })_{4}{ }^{2+}$ seems to undergo a ligand exchange during separation (from thiourea to $\mathrm{Cl}$ ) due to the large amount of chloride in the BGE, explaining the broad peak (Fig. 2.b, dashed line). The addition of thiourea in the BGE is then needed to stabilize the complex (Fig. 2.b, straight line), which can be identified by the ratio $\varepsilon_{246 \mathrm{~nm}} / \varepsilon_{270 \mathrm{~nm}}=1.63$ (similar ratio obtained by a spectrophotometric analysis, Table 1). This result is of importance due to the fact that no electrokinetic characterization of this complex was reported in the literature to the best of our knowledge.

\section{Cyclic voltammetry}

$\mathrm{CV}$ were also conducted, as illustrated in Fig. 3. On the forward scan (from $+1.2 \mathrm{~V}$ to $-0.3 \mathrm{~V}$ ), two reduction peaks are observed at $-0.09 \mathrm{~V}\left(I, \mathrm{E}_{\mathrm{red}, \mathrm{I}}\right)$ and $-0.19 \mathrm{~V}\left(I I, \mathrm{E}_{\mathrm{red}, \mathrm{II}}\right)$. They are related to two distinct reduction processes. On the backward scan, the first re-oxidation process at $-0.03 \mathrm{~V}$ (peak III) is related to reduction one (peak II), while the second re-oxidation one at $0.54 \mathrm{~V}$ (peak $I V$ ) corresponds to the cathodic reduction process $I$ (Fig. 3.a). A previous study of $\mathrm{PdCl}_{4}{ }^{2-}$ at different working electrodes [30-33] (carbon paste, palladium) reported the values of redox potential for the reduction of $\mathrm{PdCl}_{4}{ }^{2-}$ to $\mathrm{Pd}$ metallic film at around - $0.2 \mathrm{~V}$ vs. $\mathrm{Ag} / \mathrm{AgCl}$. Thus the first peak $(I)$ can be attributed to the reduction of $\mathrm{Pd}(\mathrm{II})$ onto its metallic form according to equation (1):

$$
P d C l_{4}^{2-}+2 e^{-} \rightarrow P d^{0}+4 C l^{-}
$$

The second reduction peak (II) can be attributed to the adsorption of $\mathrm{H}^{+}$on the $\mathrm{Pd}$ film deposit [34]. The oxidation peak $(I V)$ is typical of a stripping event, and can be attributed to the oxidation of the palladium film formed during the reductive scan $(0.62 \mathrm{~V} / \mathrm{SCE}$ in $1 \mathrm{~mol} / \mathrm{L} \mathrm{HCl}$ according to the literature [35]). LHV measurements (see Fig. 3.c) confirm the deposition that occurs at potential lower than $0 \mathrm{~V}$, but also the stripping in oxidizing conditions. The Pd solutions were also analyzed by $\mathrm{CV}$ in presence of thiourea, as illustrated on Fig. 3.b. Conversely to Pd solution alone in $\mathrm{HCl}$, no electrochemical reduction signal is observed in the potential range studied, for Pd:thiourea ratio 1:1 to $1: 4$, showing the occurrence of a chemical reaction. Moreover, for an excess of thiourea (Pd:thiourea ratio 1:10), an oxidation peak $(V I)$ appears with $\mathrm{E}_{\mathrm{ox}, \mathrm{e}}=+0.71 \mathrm{~V} / \mathrm{SCE}$. This oxidation process can be related to that of thiourea itself (in excess) since the potential value corresponds to that of the oxidation of thiourea alone in solution (peak 
$214 V I I)$. As no electrochemical activity is visible for Pd:thiourea ratio prior to 1:4, it can be assumed that there is a

215 complete chemical reaction between the metal ion and thiourea. The absence of reduction signal corroborates the

216 change of $\mathrm{Pd}$ complex from $\mathrm{PdCl}_{4}{ }^{2-}$ onto $\mathrm{Pd}$ (thiourea) ${ }_{4}{ }^{2+}$, which is not reducible in the considered potential range

217 (limited by the solvent reduction). Once the complex is formed, the excess of thiourea is then observed, as shown

218 with the oxidation peak for high Pd:thiourea ratio. We could therefore state that $\mathrm{Pd}$ is at a $+\mathrm{II}$. in this artificial leach

219 liquor, either as a chlorocomplex (in $\mathrm{HCl}$ ) or as a thio-chorocomplex (in $\mathrm{HCl}$ and thiourea), allowing for the

220 speciation diagram in Fig. S3.

Speciation of platinum in aqueous $\mathrm{HCl}$ solution: influence of thiourea

UV-Visible spectrophotometry

223 The UV visible spectra of Pt in artificial leach liquors are presented in Fig. 4 and data are summarized in Table 1.

224 The solution of $\mathrm{Pt}$ in $\mathrm{HCl}$ exhibits a single absorption peak at $262 \mathrm{~nm}\left(24930 \mathrm{~L}^{\mathrm{mol}}{ }^{-1} . \mathrm{cm}^{-1}\right)$. The storage of the solution at $4^{\circ} \mathrm{C}$ for 7 days shows no significant modification of the absorption spectrum, demonstrating the stability of the complex (<10\% of signal variation). The spectrophotometric characterization of $\mathrm{Pt}$ ion in $\mathrm{HCl}$ solution has been studied under different complex forms, such as hexachloroplatinic acid [36], showing that it exists under two different oxidation state of $+\mathrm{II}$ and $+\mathrm{IV}$ [23]. It is known that the complex $\mathrm{PtCl}_{6}{ }^{2-}(+\mathrm{IV})$ is stable and can be detected by UV absorption at $202 \mathrm{~nm}\left(\varepsilon=49400 \mathrm{~L}^{\mathrm{mol}} \mathrm{mol}^{-1} \cdot \mathrm{cm}^{-1}\right)$ and $262 \mathrm{~nm}\left(\varepsilon=24000 \mathrm{~L} \cdot \mathrm{mol}{ }^{-1} . \mathrm{cm}-1\right)$ [37], which is supposed to correspond to the $\mathrm{Pt}$ ion in solution (obtained in $0.1 \mathrm{~mol} / \mathrm{L} \mathrm{HClO}_{4}$ ). $\mathrm{Pt}$ ion can also remain in solution at an oxidation state of $+\mathrm{II}$, a planar tetrachlorocomplex of $\mathrm{PtCl}_{4}{ }^{2-}$, with an $\mathrm{UV}$ spectrum with a maximum absorption peak at around $220 \mathrm{~nm}$ [38]. Since no maximum intensity is measured at $220 \mathrm{~nm}$, Pt ion exists only under its oxidation state of $+\mathrm{IV}$ in the artificial leach liquor, with a ratio $\varepsilon_{202 \mathrm{~nm}} / \varepsilon_{262 \mathrm{~nm}}=3.67$ (versus 2.06 in the literature). The difference of ratio between the literature and our results is attributed to the presence of $\mathrm{NO}_{3}{ }^{-}$, which strongly absorbs at this wavelength. This ratio can thus not be used to clearly identify the chlorocomplex. .

The addition of thiourea induces changes in the optical properties supported by visual observation, depending on the Pt:thiourea ratio (1:1 to $1: 10)$. These modifications are not as fast as for $\mathrm{Pd}$ : at least one day is required before complete stabilization. The results present the UV spectra 7 days after preparation. For Pt:thiourea ratio lower than $1: 2$, a red precipitate is formed. Further addition of thiourea induces the dissolution of the precipitate and yields to an intense yellow coloration of the solution, which turns to a yellow clear coloration for the ratio 1:4. This solution exhibits an absorption peak at $251 \mathrm{~nm}\left(24915 \mathrm{~L} \cdot \mathrm{mol}^{-1} . \mathrm{cm}^{-1}\right)$, as shown on Fig. 4. Higher Pt:thiourea ratio do not lead 
to any change of the solution, but a strong increase of the UV absorption at $236 \mathrm{~nm}$ is noticed, which corresponds to the absorption of thiourea. The effect of thiourea on Pt solution has been studied in the literature, notably for the synthesis of different complexes of Pt-thiourea [16]. It has been shown that Pt at oxidation state of $+\mathrm{IV}$ can be reduced by thiourea to an oxidation state of $+\mathrm{II}$, giving a sub-product of formamide disulfide. Depending on the Pt:thiourea ratio, the resulting products were of different nature. For a ratio lower than 1:3, the main product was $\mathrm{Pt}_{2}$ (thiourea) ${ }_{4} \mathrm{Cl}_{6}$ (with a mix of $\mathrm{Pt}$ oxidation states of $+\mathrm{II}$ and $+\mathrm{IV}$ ), while for a ratio higher than $1: 6, \mathrm{Pt}(\text { thiourea })_{4} \mathrm{Cl}_{2}$ was produced (with only an oxidation state of $+\mathrm{II}$ ). Our results tend to indicate a similar trend, with the shift in Pt ion oxidation state from $+\mathrm{IV}$ to $+\mathrm{II}$, and the formation of the corresponding thiourea complex. For a ratio lower than $1: 2$, a red-brown precipitate appears, probably due to the formation of the dimer $\left[\mathrm{Pt}_{2}\left(\mathrm{thiourea}_{4} \mathrm{Cl}_{6}\right][16]\right.$. The yellow intense coloration for higher ratio is probably due to the formation of intermediate complexes till complete conversion into the Pt(thiourea) ${ }_{4}{ }^{2+}$ complex. The UV signal at $236 \mathrm{~nm}$ for excess of thiourea corresponds to free thiourea in solution, as demonstrated by analysis of $40 \mu \mathrm{mol} / \mathrm{L}$ thiourea in the same media $(0.1 \mathrm{~mol} / \mathrm{L} \mathrm{HCl})(\mathrm{Fig}$. 4).

\section{Capillary electrophoresis}

The CE separation of Pt $1 \mathrm{mmol} / \mathrm{L}$ in $\mathrm{HCl} 0.1 \mathrm{~mol} / \mathrm{L}$ was performed in negative polarity, as shown on Fig. 5. The electropherogram exhibits three main peaks of negative electrophoretic mobility $\left(1, \mu_{\mathrm{ep}, 1}=-68 \cdot 0 \pm 0.610^{-5} \mathrm{~cm}^{2} \cdot \mathrm{V}^{-1} \cdot \mathrm{s}^{-1}\right.$ $\left.; 2, \mu_{\mathrm{ep}, 2}=-77.6 \pm 0.610^{-5} \mathrm{~cm}^{2} \cdot \mathrm{V}^{-1} \cdot \mathrm{s}^{-1} ; 3, \mu_{\mathrm{ep}, 3}=-38.4 \pm 0.110^{-5} \mathrm{~cm}^{2} \cdot \mathrm{V}^{-1} \cdot \mathrm{s}^{-1}\right)$ with a ratio $\varepsilon_{210 \mathrm{~nm}} / \varepsilon_{260 \mathrm{~nm}}=1.66 \mathrm{for}$ peak 1 (Fig. 5.a). It should be noted that the third peak (3) appears after storage of the solution for 7 days. Peak 1 can be attributed to $\mathrm{PtCl}_{6}{ }^{2-}$, characterized by a ratio $\varepsilon_{210 \mathrm{~nm}} / \varepsilon_{260 \mathrm{~nm}}$ of 2.04 obtained using a standard UV analysis by spectrophotometry. Peak 2 is attributed to $\mathrm{NO}_{3}{ }^{-}$, present in the standard Pt solution. Nevertheless, it is known in the literature [39] that $\mathrm{PtCl}_{6}{ }^{2-}$ can be hydrolyzed under acidic condition into different forms. The third peak could be attributed to one of the sub-products, such as $\left[\mathrm{PtCl}_{5}\left(\mathrm{H}_{2} \mathrm{O}\right)\right]^{-}$.

Addition of thiourea in the sample up to a 1:4 ratio leads to the suppression of the characteristic peak of Pt in negative polarity. By inverting the separation polarity, one main peak (4) appears at $246 \mathrm{~nm}$, in a BGE void of thiourea (Fig. 5.b). The addition of thiourea up to $2 \mathrm{mmol} / \mathrm{L}$ in the BGE leads to a better resolved and symmetric peak $\left(5, \mu_{\mathrm{ep}}=+33 \cdot 3 \pm 0 \cdot 1 \cdot 10^{-5} \mathrm{~cm}^{2} \cdot \mathrm{V}^{-1} \cdot \mathrm{s}^{-1}\right)$. The CE experiments lead to the same conclusion as the one suggested for Pd i.e the formation of an instable complex of $\mathrm{Pt}(\text { thiourea })_{4}{ }^{2+}$ in the absence of thiourea in the BGE. The addition of thiourea in the BGE (Fig 5.b) leads to the stabilization of the Pt/thiourea complex. This result is of importance due to the fact that no electrokinetic characterization of Pt/thiourea complex was reported in the literature to our knowledge. 
271 CV was also performed with the Pt solution in absence of thiourea (Fig. 6.a). An ill-defined reduction signal $(I)$ is 272 observed on the forward scan starting at around $-0.05 \mathrm{~V}$ (Fig. 6.a), limited by reduction of the solvent, while a reoxidation peak (II) is observed at $+0.93 \mathrm{~V}$. In the presence of thiourea (Fig. 6.b), no reduction signal is observed for a 1:10 ratio, but two oxidation peaks $\left(I I I, \mathrm{E}_{\mathrm{ox}, \mathrm{III}} \approx+0.71 \mathrm{~V} ; I V, \mathrm{E}_{\mathrm{ox}, \mathrm{IV}}=+0.89 \mathrm{~V}\right)$ are visible. The exact mechanism for $\mathrm{PtCl}_{6}{ }^{2-}$ reduction has been discussed in the literature and is questionable. Some studies made the assumption of $\mathrm{Pt}$ deposition during reduction through multiple reactions pathway [32], but no observation was made in agreement with an electrodeposition process in the absence of thiourea. The importance of hydrolysis state of the complex (mono- or bi-hydrated) has been highlighted, but according to our measurements, the complex may be reduced at the electrode into an oxidation state of +II, with no visible deposition at the electrode on the LHV experiment (Fig. 6.c). $\mathrm{Pt}(\text { thiourea })_{4}{ }^{2+}$ can be oxidized into a new complex of oxidation state of $+\mathrm{IV}$ since an oxidation peak (IV) has been shown on CV measurement (Fig. 6.b). Peak $I V$ can be attributed to thiourea since the ligand itself shows an oxidation peak corresponding to the same potential value. LHV of ratio1:10 (see Fig. 6.c) presents no reduction wave, while two oxidation waves are observed, the first being attributed to free thiourea and the second to Pt complex of thiourea. As a conclusion, it can be assumed that $\mathrm{Pt}$ ion in artificial leach liquor is at an oxidation state of $+\mathrm{IV}$, as a $\mathrm{Pt}(\mathrm{Cl})_{6}{ }^{2-}$ complex, quite stable in the media, reducible by thiourea, and forming Pt(thiourea $)_{4}{ }^{2+}$ in excess of the organic ligand.

Speciation of gold in aqueous $\mathrm{HCl}$ solution: influence of thiourea

\section{UV-Visible spectrophotometry}

288 The characterization of soluble $\mathrm{Au}$ in $\mathrm{HCl} 0.14 \mathrm{~mol} / \mathrm{L}$ was performed the same way as for the other metals. UV 289 absorption spectra are shown in Fig. S4 and data are summarized in Table 1. The solution of gold in $\mathrm{HCl}$ exhibits two absorption peaks at $226 \mathrm{~nm}\left(43780 \mathrm{~L} \cdot \mathrm{mol}^{-1} \cdot \mathrm{cm}^{-1}\right)$ and $311 \mathrm{~nm}\left(7250 \mathrm{~L} \cdot \mathrm{mol}^{-1} \cdot \mathrm{cm}^{-1}\right)$. These two peaks are attributed to $\mathrm{AuCl}_{4}{ }^{-}$complex, with $\mathrm{Au}$ at an oxidation state of +III [40]. The wavelengths values are dependent on the $292 \mathrm{pH}$ of the solution, due to ligand exchange between chloride and hydroxide ion. In our experimental conditions, the $\mathrm{pH}$ is sufficiently low $(\mathrm{pH}=1)$ to stabilize the gold tetrachlorocomplex, as suggested by its stability after 7 days storage at $4{ }^{\circ} \mathrm{C}(<10 \%)$. The addition of thiourea at different Au:thiourea ratio $(1: 1$ to $1: 10)$ leads to changes of the optical properties supported by visual observation. Changes are slower than for Pd ion but faster than for Pt ion, with an evolution over one day. For a ratio below 1:1, an orange precipitate appears in solution. Further addition of 
clear coloration for the ratio 1:4, with an absorption peak for a wavelength of $242 \mathrm{~nm}\left(\varepsilon=17610 \mathrm{~L}^{\mathrm{mol}} \mathrm{mol}^{-1} . \mathrm{cm}^{-1}\right)$. Similarly to Pd and Pt ion, higher ratio doesn't lead to any visible change of the solution, but shows a strong increase of the UV absorption for a wavelength of $236 \mathrm{~nm}$ (Fig. S4). It was reported that Au at oxidation state of +III can be reduced by thiourea to an oxidation state of $+\mathrm{I}[13]$. The difference with Pt ion is that the Au ion will react differently as a function of the concentration of thiourea. Actually, $\mathrm{Au}^{+}$in absence of thiourea in $\mathrm{HCl}$ will form the chlorocomplex of $\mathrm{AuCl}_{2}{ }^{-}$, that disproportionates as described below (Equation 2) in low thiourea content. The precipitate observed at low Au:thiourea ratio solution is attributed to the formation of metallic gold particles that seem to aggregate under these conditions according to this reaction. But for higher thiourea content (ratio 1:4 and more), the $\mathrm{Au}$ ion at oxidation state $+\mathrm{I}$ can form a new complex of Au(thiourea) ${ }_{2}^{+}$, quite stable in the media [41] according to our results (with no evolution of the UV spectra after 7 days). Free thiourea remained in solution after the reaction, proved by the absorption peak at $236 \mathrm{~nm}$, characteristic of the absorption of thiourea ligand.

310 The analysis of the gold solution in absence of thiourea is shown in Fig. 7.a. A main peak is observed and detected at

$311222 \mathrm{~nm}\left(1, \mu_{\mathrm{ep}, 1}=-47.0 \pm 0.2 \cdot 10^{-5} \mathrm{~cm}^{2} \cdot \mathrm{V}^{-1} \cdot \mathrm{s}^{-1}\right)$. This single peak can be attributed to AuCl ${ }_{4}^{-}$complex in solution since 312 blank samples gave no peak. The other peaks are attributed to the matrix composition.

313 Thiourea addition in the sample leads to the suppression of the $\mathrm{CE}$ peak characteristic of $\mathrm{AuCl}_{4}{ }^{-}$. $\mathrm{CE}$ experiments 314 corroborate the transformation of $\mathrm{AuCl}_{4}^{-}$into $\mathrm{Au}$ (thiourea) ${ }_{2}^{+}$(for high thiourea content). The inversion of the 315 separation polarity (Fig. 7.b) gives one peak (3), like those obtained with Pd or Pt ion. Au(thiourea) ${ }_{2}^{+}$seems to be destabilized in a BGE without thiourea, as for Pd and Pt ion. It is possible to obtain a stabilized peak $\left(4, \mu_{\mathrm{ep}, 4}=\right.$

$\left.317+23.3 \pm 0.1 \cdot 10^{-5} \mathrm{~cm}^{2} \cdot \mathrm{V}^{-1} \cdot \mathrm{s}^{-1}\right)$ by adding thiourea in the BGE, in order to stabilize the Au/thiourea complex. This result

318 is of importance due to the fact that no electro-kinetic characterization of this complex has been performed to our 319 knowledge.

321 The analysis of gold solution by $\mathrm{CV}$ in absence of thiourea shows a reduction peak $I$ at $+0.35 \mathrm{~V}$ (Fig. 8.a), while an 322 oxidation one $(I I)$ appears on the forward reverse scan at $+1.00 \mathrm{~V} . \mathrm{AuCl}_{4}{ }^{2-}$ is reduced and deposited to form $\mathrm{Au}$ metallic layer through the reduction (a) of $\mathrm{AuCl}_{4}{ }^{-}$complex into $\mathrm{AuCl}_{2}{ }^{-}$. Actually, $\mathrm{Au}(\mathrm{I})$ has been described in the literature [40, 42-46] as unstable under certain conditions. 
This complex can dismutate according to equation (2):

$$
3 \mathrm{AuCl}_{2}^{-} \rightarrow 2 \mathrm{Au}^{0}+\mathrm{AuCl}_{4}^{2-}+2 \mathrm{Cl}^{-}
$$

This reaction leads to the formation of a metallic film, which is then oxidized (II) at higher potential, giving the typical stripping peak, similar to the behavior of Pd ion. LHV measurements (see Fig. S5) confirm the deposition that occurs at potential lower than $+0.35 \mathrm{~V}$, but also the stripping in the oxidizing condition. Depending on thiourea amount in solution, CV measurements (Fig. 8.b) show significant differences. For ratio 1:4, there are three-oxidation peaks $\left(I I I, \mathrm{E}_{\mathrm{ox}, \mathrm{III}}=+0.43 \mathrm{~V} ; I V, \mathrm{E}_{\mathrm{ox}, \mathrm{IV}} \approx+0.77 \mathrm{~V} ; V, \mathrm{E}_{\mathrm{ox}, \mathrm{eV}} \approx+1.00 \mathrm{~V}\right)$ and one reduction feature for low potential values $\left(V I, \mathrm{E}_{\text {red,VI }}<-0.2 \mathrm{~V}\right)$. In presence of larger thiourea content, the voltammogram shows one reduction peak (not as intense as for lower ratio) and one oxidation process $\left(\mathrm{VII}, \mathrm{E}_{\mathrm{ox}, \mathrm{VII}}=+0.71 \mathrm{~V}\right)$. For Au:thiourea ratio of $1: 4$, the amount of thiourea is not sufficient to convert all $\mathrm{AuCl}_{4}^{-}$into the thiourea complex. Since a complete reaction between thiourea and $\mathrm{Au}$ ion after 7 days storage seems to occur, one can suppose that no free thiourea remains in solution (no signal corresponding to thiourea is observed on CV experiment). The reduction signal VI (Fig.8.b) can be associated to the reduction of the newly formed $\mathrm{Au}$ (thiourea) ${ }_{2}{ }^{+}$complex into Au layer, while the oxidation peak $V$ could correspond to the oxidation of the metallic film formed during the reduction step. Signal VII could be attributed to the oxidation of residual thiourea onto the modified electrode. In excess of thiourea, it can be concluded that $\mathrm{AuCl}_{4}^{-}$complex is converted into $\mathrm{Au}$ (thiourea) ${ }_{2}^{+}$, which can be reduced into Au metallic deposit, while free thiourea remain in solution (attributed to peak VII). The stripping of $\mathrm{Au}^{0}$ through its oxidation is overlapped by thiourea signal. The reduction of $\mathrm{AuCl}_{4}{ }^{-}$by thiourea in solution can be demonstrated by immerging the working electrode in a solution containing the Au complex and thiourea (Fig. 8.c). The CV obtained after transfer of this electrode to a fresh $\mathrm{HCl}$ solution (without $\mathrm{Au}$ and thiourea) show a more and more intense oxidation signal while the electrode was immerged a longer time prior to the analysis. This oxidation signal is attributed to the dissolution of $\mathrm{Au}$ film that spontaneously formed at the electrode while thiourea reacts with $\mathrm{AuCl}_{4}{ }^{-}$to give $\mathrm{Au}$ at an oxidation state of $+\mathrm{I}$, that adsorbs at the electrode and further disproportionate to give $\mathrm{Au}^{0}(2)$. The low amount of thiourea leads then to the disproportionation of $\mathrm{AuCl}_{2}{ }^{-}$into the metallic film.

Also, by varying the scan rate during $\mathrm{CV}$ experiment on $\mathrm{AuCl}_{4}{ }^{-}$(see Fig. S6), the electro-reduction of $\mathrm{AuCl}_{4}{ }^{-}$was proven as being a diffusion controlled process [47]. Furthermore, no reduction signal was observed by CV after transfer of the electrode in $\mathrm{HCl}$. Thus, it can be deduced that no $\mathrm{AuCl}_{4}{ }^{-}$is adsorbed onto the surface. The gold 
deposition occurs on the carbon electrode when adding thiourea in the solution upon adsorption of $\mathrm{AuCl}_{2}{ }^{-}$species generated by reduction of the initial tetrachlorocomplex by thiourea.

Finally, real PCBs leach liquors (named LL) and $1 \mathrm{~mol} / \mathrm{L} \mathrm{HCl}$ solutions as controls named ( $\mathrm{HCl}$ ) were prepared and analyzed, either pure or spiked with $\mathrm{Pd}$ and $\mathrm{Au}(10 \mathrm{mg} / \mathrm{L}$, named LLsp, HClsp, respectively) as described in section 2.5. Solutions $\mathrm{LL}_{\mathrm{A}}$ (filtered sample), $\mathrm{LL}_{\mathrm{B}}$ (sample matrix from loading step) and $\mathrm{LL}_{\mathrm{C}}$ (elution fractions, i.e. $\mathrm{LL}_{\mathrm{C} 1}, \mathrm{LL}_{\mathrm{C} 2}$ and $\mathrm{LL}_{\mathrm{C} 3}$ ) of each leach liquor or $\mathrm{HCl}$ control, either pure or spiked, have been characterized using UV spectrophotometry, voltammetry and CE so as to identify and quantify the presence of precious metals and evaluate extraction process efficiency. Relevant characterizations obtained with each method are summarized in Table 2.

\subsubsection{UV-Visible spectrophotometry}

$\mathrm{LL}_{\mathrm{A}}$ exhibits a UV absorption signal for wavelength values inferior to $300 \mathrm{~nm}$, with a maximum at about 235 nm which is a characteristic wavelength of both chlorocomplexes of palladium and gold (Table 1). This can be attributed to solubilized PCB compounds, resulting from the leaching process with $0.18 \%(\mathrm{w} / \mathrm{v}) \mathrm{H}_{2} \mathrm{O}_{2}$ in 1 $\mathrm{mol} / \mathrm{L} \mathrm{HCl}$, as no signal was obtained for $\mathrm{HCl}$ used as blank. In this manner, it can be assumed that the weak amount of $\mathrm{H}_{2} \mathrm{O}_{2}$ initially present in the oxidative medium was totally consumed during the leaching process. The UV spectrum of $\mathrm{LL}_{\mathrm{B}}$ displays the same characteristic pattern as $\mathrm{LL}_{\mathrm{A}}$ but with overall reduced intensities that tend to indicate the retention of the absorbing compounds of interest on the extraction column. The solution collected as waste during the washing step gave no specific UV signal, just as pure $1 \mathrm{~mol} / \mathrm{L} \mathrm{HCl}$ rinsing solution, indicating no detectable desorption of absorbing compounds in acidic medium.

Regarding LLsp and HClsp (10 mg/L Pd and Au final concentration), the corresponding filtered solutions display the same characteristic UV absorption pattern with a main peak at $263 \mathrm{~nm}$ and a weak shoulder at 235 nm. Respective solutions collected as waste during the loading and washing steps both showed the disappearance of the weak shoulder at $235 \mathrm{~nm}$ and the persistence of the maximum at $263 \mathrm{~nm}$. This is consistent with previous conclusions that tend to prove the selective retention of absorbing compounds that 
could be chlorocomplexes of $\mathrm{Au}$ and Pd while an impurity detected at $263 \mathrm{~nm}$ in the spiked samples is eluted through the loading and rinsing steps[20].

Since the eluated fractions $\mathrm{LL}_{\mathrm{C}}$ and $\mathrm{HCl}_{\mathrm{C}}$ contain high concentration of thiourea $(0.5 \mathrm{~mol} / \mathrm{L})$, a strong UV signal was measured at wavelength below $300 \mathrm{~nm}$, leading to detector saturation. Thus, no characteristic UV absorption pattern could be obtained.

\subsubsection{Cyclic voltammetry}

Concerning the electrochemical properties of solutions $\mathrm{LL}_{\mathrm{A}}$ and $\mathrm{LL}_{\mathrm{B}}$, both show an oxidation peak at $0.785 \pm 0.010 \mathrm{~V} / \mathrm{SCE}$ associated to a reduction process at $0.09 \pm 0.01 \mathrm{~V} / \mathrm{SCE}$. These signals are attributed to the presence in solution of electroactive compounds resulting from the leaching process and that are not retained by the extractant. As a control, $\mathrm{HCl}_{\mathrm{A}}$ and $\mathrm{HCl}_{\mathrm{B}}$ solutions show no signal in the same potential range. After spiking, $\mathrm{LLsp}_{\mathrm{A}}$ gave a supplementary oxidation peak at $+0.63 \mathrm{~V} / \mathrm{SCE}$, which can be attributed to Pd (II), Au oxidation peak being potentially overlapped with the matrix peak $(+0.79 \mathrm{~V} / \mathrm{SCE})$. Solution $\mathrm{LLsp}_{\mathrm{B}}$ shows only one oxidation peak at $0.795 \mathrm{~V} / \mathrm{SCE}$, due to the matrix compound, and indicating the selective retention of Pd on the adsorbant. This is consistent with the voltammograms solutions since similar oxidation signals $(+0.66$ and + $0.89 \mathrm{~V} / \mathrm{SCE}$ for Pd and Au oxidation respectively) in the solution .

All the eluated solutions contain high concentration of thiourea, thus interfering oxidation signals originating from the ligand did mask the electrochemical response of any other electroactive compound in the range 0.2 to 1.2 V/SCE. Therefore, no characteristic electrochemical pattern could be obtained.

\subsection{2 : Electrokinetic quantitation}

In order to demonstrate the extraction yield efficiency of the all procedure, solutions $\mathrm{LL}_{\mathrm{C}}$ were analyzed by $\mathrm{CE}$ so as to evidence the potential presence of thiourea-complexes of precious metals. The extraction yield was estimated on the basis of a theoretical expected concentration of thiourea complexes equal to $66.7 \mathrm{mg} / \mathrm{L}$ in $\mathrm{Pd}$ and $\mathrm{Au}$, based on $100 \%$ recovery and a 6.67 concentration factor (volume ratio in between solution A and solution $\mathrm{C}-1)$. 
Solution LLsp $\mathrm{C}_{1}$ (Fig.9.a) gave 3 resolved peaks $\left(1, \mu_{\mathrm{ep}, 1}=-44.1 \pm 1.5 .10^{-5} \mathrm{~cm}^{2} \cdot \mathrm{V}^{-1} \cdot \mathrm{s}^{-1} ; 2, \mu_{\mathrm{ep}, 2}=-36.1 \pm 1.4 .10^{-5}\right.$ $\left.\mathrm{cm}^{2} \cdot \mathrm{V}^{-1} \cdot \mathrm{s}^{-1} ; 3, \mu_{\mathrm{ep}, 3}=-27.9 \pm 1 \cdot 3 \cdot 10^{-5} \mathrm{~cm}^{2} \cdot \mathrm{V}^{-1} \cdot \mathrm{s}^{-1}\right)$. Since no significant peak could be identified when analyzing solutions $\operatorname{LLsp}_{\mathrm{C} 2}$ and $\operatorname{LLsp}_{\mathrm{C} 3}$ (due to the absence of metals in solution or in quantity inferior to the LOD), attention was given to the results obtain on solution LLsp $\mathrm{C}_{\mathrm{C}}$. Peak 1 was attributed to Pd(thiourea) ${ }_{4}{ }^{2+}$ and peak 2 to $\mathrm{Au}$ (thiourea) ${ }_{2}{ }^{+}$by individual separation of each metal complex, prepared in $0.5 \mathrm{~mol} / \mathrm{L}$ thiourea $/ 0.1 \mathrm{~mol} / \mathrm{L}$ HCl. CE-UV allowed the quantitation of thiourea complexes, after determination of the calibration curves for each complex in a concentration range from 25 to $125 \mathrm{mg} / \mathrm{L}$ (Fig.9.b), leading to limits of detection of 1.2 and $3.8 \mathrm{mg} / \mathrm{L}$ for thiourea complexes of $\mathrm{Pd}$ and $\mathrm{Au}$, respectively, which is inferior to what is expected for real solutions (with final concentration of thiourea complexes superior to $5 \mathrm{mg} / \mathrm{L}$ ). The extraction yield of Pd- and Au-thiourea complexes obtained from solution $\mathrm{LLsp}_{\mathrm{C} 1}$ are reported in Fig.9.c for both HClsp (taken as blank) and LLsp. Extraction yields of $94 \%$ and $101 \pm 13 \%(\mathrm{n}=3$, on independent cartridges) for Pd and $85 \%$ and $37 \pm 10 \%$ for Au were calculated for HClsp and LLsp, respectively. Thus solutions at a final concentration of $67.6 \pm 8.5 \mathrm{mg} / \mathrm{L}$ in $\mathrm{Pd}$ and $27.6 \pm 6.4 \mathrm{mg} / \mathrm{L}$ in $\mathrm{Au}$ were obtained after purification and extraction of the spiked leach liquor on the cartridge.

A matrix effect can be highlighted here on the extraction yield of $\mathrm{Au}$, decreasing from $85 \%$ in $\mathrm{HCl}$ to $37 \%$ in leach liquor. This can be due to Au complexation by matrix agents, thus changing the interaction nature between the extractant and the metal or by competition between Au-chlorocomplexes and an interferent potentially retained by the cartridge, as suggested by the detection of a third peak in solution LLsp $\mathrm{P}_{\mathrm{C}}$ of spiked and non-spiked leach liquor (results not shown). This peak could be tentatively assigned to the presence of copper in leach liquor matrix since the analysis of a $5 \mathrm{mmol} / \mathrm{L} \mathrm{CuCl}_{2}$ solution prepared in $0.5 \mathrm{~mol} / \mathrm{L}$ thiourea / $0.1 \mathrm{~mol} / \mathrm{L} \mathrm{HCl}$ gave a peak of similar assymetry and migration time in capillary zone electrophoresis. Furthermore, the $\mathrm{CE}$ analysis of solution $\mathrm{LLsp}_{\mathrm{C} 1}$ resulting from leach liquor spiked with only $\mathrm{Au}$ gave a recovery efficiency of $111 \%$, meaning that the loss of efficiency could probably originate from a competing effect with Pd. Complementary purification steps could be proposed to increase the recovery of Au, varying the cartridge composition or thiourea concentration. Therefore CE appears as a very interesting methodology to precisely determine the concentration in leach liquors, and to help for controlling extraction processes for strategic metal recycling. 


\section{Conclusion}

428 The speciation of Pd, Pt and Au was studied by different methodologies (UV-Visible spectrophotometry, cyclic 429 voltammetry and capillary electrophoresis) in leach liquors that mimic leaching treatments (HCl liquors with or 430 without thiourea) before recycling processes. UV spectra allowed identifying chlorocomplexes in $\mathrm{HCl}$ solution and evidencing the presence of different thiourea complexes when adding thiourea at different concentrations in $\mathrm{HCl}$ solutions. A difference in the kinetics of thiourea complexation in this leach liquor was demonstrated for three precious metals. It was shown that thiourea reduces $\mathrm{Pt}$ and $\mathrm{Au}$, leading to new complexes depending whether on the concentration of thiourea and chloride ion in the media, while ligand exchange happens for Pd ion with no oxidation state change. CE separation in the different BGEs confirmed the formation and stability of these identified complexes, according to BGE composition. Furthermore, the electrochemical activities of chloro- and thiourea- complexes were determined by $\mathrm{CV}$, indicating that thiourea complexes did not present any apparent electrochemical activity in the potential range of study. Thanks to these three methodologies, the speciation of $\mathrm{Pd}, \mathrm{Pt}$ and $\mathrm{Au}$ could be established in these specific conditions mimicking the leaching process, opening the way for a deeper understanding and control of the different steps for developing new recycling processes of these strategic metals from WEEE.

Besides, CE proved to be a powerful methodology for rapid and easy quantitation of leach liquors, before processing to precious metal recovery and valorization. With a LOD of 1.2 and $3.8 \mathrm{mg} / \mathrm{L}$ for Pd and $\mathrm{Au}-$ thiourea complexes respectively, inferior to the metals concentration in leach liquors, CE was used to estimate the extraction yield of a solid phase extraction process by quantitation of thiourea complexes in spiked leach liquor. The extraction yields for each metal separately was determined as $100 \%$, and possible matrix interference or metal competition was evidenced. Therefore CE was proved as a very interesting methodology to precisely quantitate strategic metals in leach liquors, opening the way for an automated control of extraction processes for strategic metal recycling. 


\section{Acknowledgements}

This work was supported by the French Environment and Energy Management Agency (ADEME) and the Chaire "Mines Urbaines" from ParisTech foundation, supported by Eco-systèmes, which provided the waste PCBs.

\section{References}

1. Union PO of the E (2018) Report on critical raw materials and the circular economy. https://publications.europa.eu/en/publication-detail/-/publication/d1be1b43-e18f-11e8-b69001aa75ed71a1/language-en/format-PDF. Accessed 20 Dec 2018

2. Rapport annuel du registre des Déchets d'équipements électriques et électroni... In: ADEME. http://www.ademe.fr/rapport-annuel-registre-dechets-dequipements-electriques-electroniques-donnees-2016. Accessed 15 Feb 2018

3. Mudd GM, Jowitt SM, Werner TT (2018) Global platinum group element resources, reserves and mining - A critical assessment. Sci Total Environ 622-623:614-625 . https://doi.org/10.1016/j.scitotenv.2017.11.350

4. Bourse en direct, Cours actions et dérivés - Boursorama. http://www.boursorama.com/bourse/. Accessed 15 Feb 2018

5. Cui J, Zhang L (2008) Metallurgical recovery of metals from electronic waste: A review. J Hazard Mater 158:228-256 . https://doi.org/10.1016/j.jhazmat.2008.02.001

6. Zhang Z, Zhang F-S (2014) Selective recovery of palladium from waste printed circuit boards by a novel nonacid process. J Hazard Mater 279:46-51 . https://doi.org/10.1016/j.jhazmat.2014.06.045

7. Hubicki Z, Wołowicz A (2009) A comparative study of chelating and cationic ion exchange resins for the removal of palladium(II) complexes from acidic chloride media. J Hazard Mater 164:1414-1419 . https://doi.org/10.1016/j.jhazmat.2008.09.053

8. Behnamfard A, Salarirad MM, Veglio F (2013) Process development for recovery of copper and precious metals from waste printed circuit boards with emphasize on palladium and gold leaching and precipitation. Waste Manag 33:2354-2363 . https://doi.org/10.1016/j.wasman.2013.07.017

9. Quinet P, Proost J, Lierde AV (2005) Recovery of precious metals from electronic scrap by hydrometallurgical processing routes. Miner Metall Process 22:17

10. Lin T-L, Lien H-L (2013) Effective and Selective Recovery of Precious Metals by Thiourea Modified Magnetic Nanoparticles. Int J Mol Sci 14:9834-9847 . https://doi.org/10.3390/ijms14059834

11. Zhou L, Liu J, Liu Z (2009) Adsorption of platinum(IV) and palladium(II) from aqueous solution by thioureamodified chitosan microspheres. J Hazard Mater 172:439-446 . https://doi.org/10.1016/j.jhazmat.2009.07.030

12. Izatt RM (2016) Metal Sustainability: Global Challenges, Consequences, and Prospects. John Wiley \& Sons

13. Groenewald T (1977) Potential applications of thiourea in the processing of gold. J South Afr Inst Min Metall $77: 217-223$

14. Ruzmetov U, Gevorgyan A (2014) Formation of Thiourea Complexes by Platinum and Palladium and Amperometrical Method. Adv Sci J 2014:82-85 . https://doi.org/10.15550/ASJ.2014.07.082 
15. Sun PP, Lee MS (2011) Separation of Pt(IV) and Pd(II) from the loaded Alamine 336 by stripping. Hydrometallurgy 109:181-184 . https://doi.org/10.1016/j.hydromet.2011.06.003

16. Kováčová J, Gažo J (1980) Reactions of chloroplatinum(IV) complex with thiourea and its alkyl derivatives. Collect Czechoslov Chem Commun 45:1331-1335 . https://doi.org/10.1135/cccc19801331

17. Hubau A, Chagnes A, Minier M, Touzé S, Chapron S, Guezennec A-G (2019) Recycling-oriented methodology to sample and characterize the metal composition of waste Printed Circuit Boards. Waste Manag 91:62-71 . https://doi.org/10.1016/j.wasman.2019.04.041

18. Izatt RM, Izatt SR, Izatt NE, Krakowiak KE, Bruening RL, Navarro L (2015) Industrial applications of molecular recognition technology to separations of platinum group metals and selective removal of metal impurities from process streams. Green Chem 17:2236-2245 . https://doi.org/10.1039/C4GC02188F

19. Izatt RM, Pawlak Krystyna, Bradshaw JS, Bruening RL (1991) Thermodynamic and kinetic data for macrocycle interactions with cations and anions. Chem Rev 91:1721-2085 . https://doi.org/10.1021/cr00008a003

20. Hasegawa H, Barua S, Wakabayashi T, Mashio A, Maki T, Furusho Y, Rahman IMM (2018) Selective recovery of gold, palladium, or platinum from acidic waste solution. Microchem J 139:174-180 . https://doi.org/10.1016/j.microc.2018.02.025

21. Martell AE, Smith RM (1982) Critical Stability Constants: First Supplement. Springer US

22. Doyle FM, Woods R, Kelsall GH (2010) Electrochemistry in Mineral and Metal Processing 8 (EMMP 8). The Electrochemical Society

23. Bernardis FL, Grant RA, Sherrington DC (2005) A review of methods of separation of the platinum-group metals through their chloro-complexes. React Funct Polym 65:205-217 . https://doi.org/10.1016/j.reactfunctpolym.2005.05.011

24. Høgdahl OT (1961) The radiochemistry of palladium. National Academy of Sciences

25. Wojnicki M, Socha RP, Pędzich Z, Mech K, Tokarski T, Fitzner K (2018) Palladium(II) Chloride Complex Ion Recovery from Aqueous Solutions Using Adsorption on Activated Carbon. J Chem Eng Data 63:702-711 . https://doi.org/10.1021/acs.jced.7b00885

26. Peyronel G, Marcotrigiano G, Battistuzzi R (1972) Radiochromatographic, conductometric and highfrequency titration studies on the thiourea complexes of palladium(II) and platinum(II). J Chromatogr A 70:117-127 . https://doi.org/10.1016/S0021-9673(01)91064-7

27. Marcotrigiano G, Battistuzzi R, Peyronel G (1973) Binuclear halogen-bridged complexes of palladium(II) with thiourea: Pd2Tu2X4 and their bridge-splitting reactions. J Inorg Nucl Chem 35:2265-2270 . https://doi.org/10.1016/0022-1902(73)80290-8

28. Kahn ES, Rheingold AL, Shupack SI (1993) Synthesis and properties of palladium(II) complexes with sulfur ligands. J Crystallogr Spectrosc Res 23:697-710 . https://doi.org/10.1007/BF01187271

29. Zhang H-W, Jia L, Hu Z-D (1995) Determination of palladium(II) as chloro complex by capillary zone electrophoresis. J Chromatogr A 704:242-246 . https://doi.org/10.1016/0021-9673(95)00121-3

30. Elding LI (1972) Palladium(II) halide complexes. I. Stabilities and spectra of palladium(II) chloro and bromo aqua complexes. Inorganica Chim Acta 6:647-651 . https://doi.org/10.1016/S0020-1693(00)91874-7 
31. Polotnyanko NA, Khodakovskii IL (2014) Thermodynamic properties of Pd chloride complexes and the $\mathrm{Pd} 2+(\mathrm{aq})$ ion in aqueous solutions. Geochem Int 52:46-56 . https://doi.org/10.1134/S0016702914010054

32. Adekola FA, Diaw M, Colin C, Bauer D (1992) Electrochemical study of some palladium compounds at a carbon paste electrode - application to the determination of palladium in oxidation automotive catalysts. Electrochimica Acta 37:2491-2495 . https://doi.org/10.1016/0013-4686(92)87089-I

33. Lubert K-H, Guttmann M, Beyer L (1996) Voltammetric study of the immobilization of palladium at the surface of carbon paste electrodes. Electroanalysis 8:320-325 . https://doi.org/10.1002/elan.1140080404

34. Gu S, Wang X, Wei Y, Fang B (2014) Mechanism for nucleation and growth of electrochemical deposition of palladium(II) on a platinum electrode in hydrochloric acid solution. Sci China Chem 57:755-762 . https://doi.org/10.1007/s11426-013-5026-2

35. Griffith WP, Robinson SD, Swars K (1989) Pd Palladium: Palladium Compounds, 8th ed. Springer-Verlag, Berlin Heidelberg

36. Yasin HM, Denuault G, Pletcher D (2009) Studies of the electrodeposition of platinum metal from a hexachloroplatinic acid bath. J Electroanal Chem 633:327-332 . https://doi.org/10.1016/j.jelechem.2009.06.020

37. Znakovskaya IV, Glebov EM (2016) Photochemistry of the PtCl62-complex in acidic aqueous solutions. Mendeleev Commun 26:35-37 . https://doi.org/10.1016/j.mencom.2016.01.014

38. van Wyk P-H, Gerber WJ, Koch KR (2011) A robust method for speciation, separation and photometric characterization of all $[\mathrm{PtCl}-\mathrm{nBrn}] 2-(\mathrm{n}=0-6)$ and $[\mathrm{PtCl} 4-\mathrm{nBrn}] 2-(\mathrm{n}=0-4)$ complex anions by means of ion-pairing RP-HPLC coupled to ICP-MS/OES, validated by high resolution 195Pt NMR spectroscopy. Anal Chim Acta 704:154-161 . https://doi.org/10.1016/j.aca.2011.07.037

39. Spieker WA, Liu J, Miller JT, Kropf AJ, Regalbuto JR (2002) An EXAFS study of the co-ordination chemistry of hydrogen hexachloroplatinate(IV): 1. Speciation in aqueous solution. Appl Catal Gen 232:219235 . https://doi.org/10.1016/S0926-860X(02)00116-3

40. Peck JA, Tait CD, Swanson BI, Brown GE (1991) Speciation of aqueous gold(III) chlorides from ultraviolet/visible absorption and Raman/resonance Raman spectroscopies. Geochim Cosmochim Acta 55:671-676 . https://doi.org/10.1016/0016-7037(91)90332-Y

41. Marsden J, House I (2006) The Chemistry of Gold Extraction. SME

42. Alarnes-Varela G, Costa-García A (1997) Determination of gold by anodic stripping voltammetry with carbon fiber ultramicroelectrodes. Electroanalysis 9:1262-1266 . https://doi.org/10.1002/elan.1140091609

43. Gallego JH, Castellano CE, Calandra AJ, Arvia AJ (1975) The electrochemistry of gold in acid aqueous solutions containing chloride ions. J Electroanal Chem Interfacial Electrochem 66:207-230 . https://doi.org/10.1016/S0022-0728(75)80004-0

44. Usher A, McPhail DC, Brugger J (2009) A spectrophotometric study of aqueous Au(III) halide-hydroxide complexes at $25-80^{\circ} \mathrm{C}$. Geochim Cosmochim Acta 73:3359-3380 . https://doi.org/10.1016/j.gca.2009.01.036

45. Pan P, Wood SA (1991) Gold-chloride complexes in very acidic aqueous solutions and at temperatures 25-300 ${ }^{\circ} \mathrm{C}$ : A laser Raman spectroscopic study. Geochim Cosmochim Acta 55:2365-2371 . https://doi.org/10.1016/0016-7037(91)90112-I

46. F. A. Cotton, Wilkinson (2007) Advanced inorganic chemistry, 6th edition. Wiley India Pvt. Limited 
47. Bard AJ, Faulkner LR (2000) Electrochemical Methods: Fundamentals and Applications. Wiley

48. HosoyaHaruo, TanakaJiro, NagakuraSaburo (2006) Ultraviolet Absorption Spectra of Aqueous Solutions and Single Crystals of Thioacetamide and Thiourea. Bull Chem Soc Jpn. https://doi.org/10.1246/bcsj.33.850

49. King SR, Massicot J, McDonagh AM (2015) A Straightforward Route to Tetrachloroauric Acid from Gold Metal and Molecular Chlorine for Nanoparticle Synthesis. Metals 5:1454-1461 . https://doi.org/10.3390/met5031454

50. Petter PMH, Veit HM, Bernardes AM (2014) Evaluation of gold and silver leaching from printed circuit board of cellphones. Waste Manag 34:475-482 . https://doi.org/10.1016/j.wasman.2013.10.032

51. Gurung M, Adhikari BB, Kawakita H, Ohto K, Inoue K, Alam S (2013) Recovery of gold and silver from spent mobile phones by means of acidothiourea leaching followed by adsorption using biosorbent prepared from persimmon tannin. Hydrometallurgy 133:84-93 . https://doi.org/10.1016/j.hydromet.2012.12.003

52. Jing-ying L, Xiu-li X, Wen-quan L (2012) Thiourea leaching gold and silver from the printed circuit boards of waste mobile phones. Waste Manag 32:1209-1212 . https://doi.org/10.1016/j.wasman.2012.01.026

53. Birloaga I, Coman V, Kopacek B, Vegliò F (2014) An advanced study on the hydrometallurgical processing of waste computer printed circuit boards to extract their valuable content of metals. Waste Manag 34:2581-2586 . https://doi.org/10.1016/j.wasman.2014.08.028

54. Lee C-H, Tang L-W, Popuri SR (2011) A study on the recycling of scrap integrated circuits by leaching. Waste Manag Res 29:677-685 . https://doi.org/10.1177/0734242X10380995

55. Birloaga I, Vegliò F (2016) Study of multi-step hydrometallurgical methods to extract the valuable content of gold, silver and copper from waste printed circuit boards. J Environ Chem Eng 4:20-29 . https://doi.org/10.1016/j.jece.2015.11.021

56. Ficeriová J, Baláž P, Gock E (2011) Leaching of gold, silver and accompanying metals from circuit boards (PCBs) waste. Acta Montan Slovaca 16:

57. Ha VH, Lee J, Jeong J, Hai HT, Jha MK (2010) Thiosulfate leaching of gold from waste mobile phones. J Hazard Mater 178:1115-1119 . https://doi.org/10.1016/j.jhazmat.2010.01.099

58. Oh CJ, Lee SO, Yang HS, Ha TJ, Kim MJ (2003) Selective Leaching of Valuable Metals from Waste Printed Circuit Boards. J Air Waste Manag Assoc 53:897-902 . https://doi.org/10.1080/10473289.2003.10466230

59. Kim E, Kim M, Lee J, Pandey BD (2011) Selective recovery of gold from waste mobile phone PCBs by hydrometallurgical process. J Hazard Mater 198:206-215 . https://doi.org/10.1016/j.jhazmat.2011.10.034

60. Jadhav U, Hocheng H (2015) Hydrometallurgical Recovery of Metals from Large Printed Circuit Board Pieces. Sci Rep 5: . https://doi.org/10.1038/srep14574 


\section{Figures Captions}

Fig. 1 UV absorption spectra of Pd solution with or without thiourea at different molar ratios. Straight line: fresh 20 $\mu \mathrm{mol} / \mathrm{L} \mathrm{Pd}$ in $0.1 \mathrm{~mol} / \mathrm{L} \mathrm{HCl}$. Dash line: $20 \mu \mathrm{mol} / \mathrm{L} \mathrm{Pd}$ in $0.1 \mathrm{~mol} / \mathrm{L} \mathrm{HCl}$ after 7 days storage. Dotted line: $40 \mu \mathrm{mol} / \mathrm{L}$ thiourea in $0.1 \mathrm{~mol} / \mathrm{L} \mathrm{HCl}$. Square: $20 \mu \mathrm{mol} / \mathrm{L} \mathrm{Pd}+20 \mu \mathrm{mol} / \mathrm{L}$ thiourea in $0.1 \mathrm{~mol} / \mathrm{L} \mathrm{HCl}$. Tile: $20 \mu \mathrm{mol} / \mathrm{L} \mathrm{Pd}+80$ $\mu \mathrm{mol} / \mathrm{L}$ thiourea in $0,1 \mathrm{~mol} / \mathrm{L} \mathrm{HCl}$. Triangle: $20 \mu \mathrm{mol} / \mathrm{L} \mathrm{Pd}+200 \mu \mathrm{mol} / \mathrm{L}$ thiourea in $0.1 \mathrm{~mol} / \mathrm{L} \mathrm{HCl}$

Fig. 2 Electrophoretic separation of Pd ion (a) $1 \mathrm{mmol} / \mathrm{L}$ diluted in $0.1 \mathrm{~mol} / \mathrm{L} \mathrm{HCl}$, separated in BGE $(50 \mathrm{mmol} / \mathrm{L} \mathrm{NaCl} / 1$ $\mathrm{mmol} / \mathrm{L} \mathrm{HCl}$ ) under a voltage of $-11 \mathrm{kV}$ and detected at 222 and $270 \mathrm{~nm}$. (b) $1 \mathrm{mmol} / \mathrm{L}$ diluted in $10 \mathrm{mmol} / \mathrm{L}$ thiourea $/ 0.1$ $\mathrm{mol} / \mathrm{L} \mathrm{HCl}$, separated in BGE with or without $2 \mathrm{mmol} / \mathrm{L}$ thiourea under a voltage of $+11 \mathrm{kV}$, and detected at $246 \mathrm{~nm}$. Separation conditions: Fused silica, capillary length $35 \mathrm{~cm}$; detector $26.5 \mathrm{~cm} ; 50 \mu \mathrm{m}$ internal diameters. Injection condition: successive injections of sample and BGE (30 mbar during $2 \mathrm{~s}$ )

Fig. 3 (a) Cyclic voltammetry at glassy carbon electrode of palladium solutions in $\mathrm{HCl}$ (scan rate $100 \mathrm{mV} / \mathrm{s}$ ). Straight line: fresh $\mathrm{Pd} 1 \mathrm{mmol} / \mathrm{L}$ in $\mathrm{HCl} 0.1 \mathrm{~mol} / \mathrm{L}$ after preparation. Dash line: $\mathrm{Pd} 1 \mathrm{mmol} / \mathrm{L}$ in $\mathrm{HCl} 0.1 \mathrm{~mol} / \mathrm{L}$ after 7 days storage. Dotted line: $\mathrm{HCl} 0.1 \mathrm{~mol} / \mathrm{L}$. (b) Cyclic voltammetry at glassy carbon electrode of palladium solutions in $\mathrm{HCl}$ and thiourea (scan rate $100 \mathrm{mV} / \mathrm{s}$ ). Straight line: $\mathrm{Pd} 1 \mathrm{mmol} / \mathrm{L}$ + thiourea $4 \mathrm{mmol} / \mathrm{L}$ in $\mathrm{HCl} 0.1 \mathrm{~mol} / \mathrm{L}$. Dashed line: $\mathrm{Pd} 1 \mathrm{mmol} / \mathrm{L}+$ thiourea $10 \mathrm{mmol} / \mathrm{L}$ in $\mathrm{HCl} 0.1 \mathrm{~mol} / \mathrm{L}$. Dotted line: thiourea $2 \mathrm{mmol} / \mathrm{L}$ in $\mathrm{HCl} 0.1 \mathrm{~mol} / \mathrm{L}$. (c) Linear hydrodynamic voltammetry of a solution of $\mathrm{Pd} 1 \mathrm{mmol} / \mathrm{L}$ in $\mathrm{HCl} 0.1 \mathrm{~mol} / \mathrm{L}$ at glassy carbon electrode at $0.1 \mathrm{~V} / \mathrm{s}$. Straight line: $\mathrm{Pd} 1$ $\mathrm{mol} / \mathrm{LM}$ in $\mathrm{HCl} 0.1 \mathrm{~mol} / \mathrm{L}$ after preparation, from -0.3 to $+1.2 \mathrm{~V}$. Dash line: $\mathrm{Pd} 1 \mathrm{mmol} / \mathrm{L}$ in $\mathrm{HCl} 0.1 \mathrm{~mol} / \mathrm{L}$ after preparation, from +0.9 to $-0.3 \mathrm{~V}$

Fig. 4 UV absorption spectra of platinum solution with or without thiourea at different molar ratios. Straight line: fresh 20 $\mu \mathrm{mol} / \mathrm{L} \mathrm{Pt}$ in $0.1 \mathrm{~mol} / \mathrm{L} \mathrm{HCl}$. Dash line: $20 \mu \mathrm{mol} / \mathrm{L} \mathrm{Pt}$ in $0.1 \mathrm{~mol} / \mathrm{L} \mathrm{HCl}$ after 7 days storage. Dotted line: $40 \mu \mathrm{mol} / \mathrm{L}$ thiourea in $0.1 \mathrm{~mol} / \mathrm{L} \mathrm{HCl}$. Square: $20 \mu \mathrm{mol} / \mathrm{L} \mathrm{Pt}+20 \mu \mathrm{mol} / \mathrm{L}$ thiourea in $0.1 \mathrm{~mol} / \mathrm{L} \mathrm{HCl}$. Tile: $20 \mu \mathrm{mol} / \mathrm{L} \mathrm{Pt}+80 \mu \mathrm{mol} / \mathrm{L}$ thiourea in $0.1 \mathrm{~mol} / \mathrm{L} \mathrm{HCl}$. Triangle: $20 \mu \mathrm{mol} / \mathrm{L} \mathrm{Pt}+200 \mu \mathrm{mol} / \mathrm{L}$ thiourea in $0.1 \mathrm{~mol} / \mathrm{L} \mathrm{HCl}$

Fig. 5 Electrophoretic analysis of Pt ion (a) $1 \mathrm{mmol} / \mathrm{L}$ diluted in $\mathrm{HCl} 0.1 \mathrm{~mol} / \mathrm{L}$, separated in $\mathrm{BGE}(\mathrm{NaCl} 50 \mathrm{mmol} / \mathrm{L} / \mathrm{HCl}$ $1 \mathrm{mmol} / \mathrm{L}$ ) under a voltage of $-11 \mathrm{kV}$, and detected at 210 and $260 \mathrm{~nm}$. (b) $1 \mathrm{mmol} / \mathrm{L}$ diluted in thiourea $10 \mathrm{mmol} / \mathrm{L} / \mathrm{HCl}$ $0.1 \mathrm{~mol} / \mathrm{L}$, separated in BGE with or without $2 \mathrm{mmol} / \mathrm{L}$ thiourea under a voltage of $+11 \mathrm{kV}$, and detected at $246 \mathrm{~nm}$. Separation conditions: Fused silica, capillary length $35 \mathrm{~cm}$; detector $26.5 \mathrm{~cm} ; 50 \mu \mathrm{m}$ internal diameters. Injection condition: successive injections of sample and BGE (30 mbar during $2 \mathrm{~s}$ )

Fig. 6 (a) Cyclic voltammetry at glassy carbon electrode of $\mathrm{Pt}$ in $\mathrm{HCl}$ (scan rate $100 \mathrm{mV} / \mathrm{s}$ ). Straight line: fresh Pt 1 $\mathrm{mmol} / \mathrm{L}$ in $\mathrm{HCl} 0.1 \mathrm{~mol} / \mathrm{L}$ after preparation. Dash line: $\mathrm{Pt} 1 \mathrm{mmol} / \mathrm{L}$ in $\mathrm{HCl} 0.1 \mathrm{~mol} / \mathrm{L}$ after 7 days storage. Dotted line: $\mathrm{HCl}$ $0.1 \mathrm{~mol} / \mathrm{L}$. (b) Cyclic voltammetry at glassy carbon electrode of Pt in $\mathrm{HCl}$ and thiourea (scan rate $100 \mathrm{mV} / \mathrm{s}$ ). Straight line: Pt $1 \mathrm{mmol} / \mathrm{L}$ + thiourea $4 \mathrm{mmol} / \mathrm{L}$ in $\mathrm{HCl} 0.1 \mathrm{~mol} / \mathrm{L}$. Dash line: Pt $1 \mathrm{mmol} / \mathrm{L}$ + thiourea $10 \mathrm{mmol} / \mathrm{L}$ in $\mathrm{HCl} 0.1 \mathrm{~mol} / \mathrm{L}$. Dotted line: thiourea $2 \mathrm{mmol} / \mathrm{L}$ in $\mathrm{HCl} 0.1 \mathrm{~mol} / \mathrm{L}$. (c) Linear hydrodynamic voltammetry of different platinum solutions at glassy carbon electrode at $0.1 \mathrm{~V} / \mathrm{s}$. Straight line: $\mathrm{Pt} 1 \mathrm{mmol} / \mathrm{L}$ in $\mathrm{HCl} 0.1 \mathrm{~mol} / \mathrm{L}$ after preparation, from -0.3 to $+1.2 \mathrm{~V}$. Dash line: Pt $1 \mathrm{mmol} / \mathrm{L}$ in $\mathrm{HCl} 0.1 \mathrm{~mol} / \mathrm{L}$ after preparation, from +1.2 to $-0.3 \mathrm{~V}$. Thin dash line: $\mathrm{Pt} 1 \mathrm{mmol} / \mathrm{L}+$ thiourea 5 $\mathrm{mmol} / \mathrm{L}$ in $\mathrm{HCl} 0.1 \mathrm{~mol} / \mathrm{L} 7$ days after preparation, , from -0.3 to $+1.2 \mathrm{~V}$

Fig. 7 Electrophoretic separation of Au ion (a) $0.5 \mathrm{mmol} / \mathrm{L}$ diluted in $\mathrm{HCl} 0.14 \mathrm{~mol} / \mathrm{L}$, separated in $\mathrm{BGE}(\mathrm{NaCl} 50 \mathrm{mmol} / \mathrm{L}$ $/ \mathrm{HCl} 1 \mathrm{mmol} / \mathrm{L}$ ) under a voltage of $-11 \mathrm{kV}$, and detected at 222 and $270 \mathrm{~nm}$. (b) $0.5 \mathrm{mmol} / \mathrm{L}$ diluted in thiourea $5 \mathrm{mmol} / \mathrm{L} /$ $\mathrm{HCl} 0.14 \mathrm{~mol} / \mathrm{L}$, separated in BGE with or without $2 \mathrm{mmol} / \mathrm{L}$ thiourea under a voltage of $+11 \mathrm{kV}$, and detected at $246 \mathrm{~nm}$. Separation conditions: Fused silica, capillary length $35 \mathrm{~cm}$; detector $26.5 \mathrm{~cm} ; 50 \mu \mathrm{m}$ internal diameters. Injection condition: successive injections of sample and BGE (30 mbar during 2s)

Fig. 8 (a) Cyclic voltammetry at glassy carbon electrode of Au solutions in $\mathrm{HCl}$ (scan rate $100 \mathrm{mV} / \mathrm{s}$ ). Straight line: fresh Au $0.5 \mathrm{mmol} / \mathrm{L}$ in $\mathrm{HCl} 0.14 \mathrm{~mol} / \mathrm{L}$. Dash line: $\mathrm{Au} 0.5 \mathrm{mmol} / \mathrm{L}$ in $\mathrm{HCl} 0.14 \mathrm{~mol} / \mathrm{L}$ after 7 days storage. Dotted line: $\mathrm{HCl}$ $0.14 \mathrm{~mol} / \mathrm{L}$; (b) Cyclic voltammetry at glassy carbon electrode of Au solutions in $\mathrm{HCl}$ and thiourea (scan rate $100 \mathrm{mV} / \mathrm{s}$ ). Straight line: Au $0.5 \mathrm{mmol} / \mathrm{L}$ + thiourea $2 \mathrm{mmol} / \mathrm{L}$ in $\mathrm{HCl} 0.14 \mathrm{~mol} / \mathrm{L}$. Dash line: Au $0.5 \mathrm{mmol} / \mathrm{L}+$ thiourea $5 \mathrm{mmol} / \mathrm{L}$ in 
647

648
$\mathrm{HCl} 0.14 \mathrm{~mol} / \mathrm{L}$. Dotted line: thiourea $2 \mathrm{mmol} / \mathrm{L}$ in $\mathrm{HCl} 0.1 \mathrm{~mol} / \mathrm{L}$. CV from +1.2 to -0.3 to $+1.2,100 \mathrm{mV} / \mathrm{s}$; (c) Straight line: Right after immersion of the WE in freshly prepared $0.5 \mathrm{mmol} / \mathrm{L} \mathrm{Au}, 0.5 \mathrm{mmol} / \mathrm{L}$ thiourea in $0.1 \mathrm{~mol} / \mathrm{L} \mathrm{HCl}$. Dash line: 1 min after immersion of the WE in the same media. Dotted line: 10 min after immersion of the WE in the same media

Fig. 9 (a) CE analysis of Solutions $\mathrm{C} 1$ to $\mathrm{C} 3$ collected as 3 successive fractions of $3.75 \mathrm{~mL}$ after the treatment on Analig® PM-07 SPE cartridge of a Pd- and Au-spiked leach liquor; (b) calibration curve for the quantitation of Pd and Au -thiourea complexes (at $246 \mathrm{~nm}$ ) by CE-UV (metals prepared in $10 \mathrm{mmol} / \mathrm{L}$ Thiourea / $0.1 \mathrm{~mol} / \mathrm{L} \mathrm{HCl}$; it can be noticed that error bars were calculated and smaller than the used marker size), and (c) calculated extraction yield for Pd- and Au-spiked samples (leach liquor and $1 \mathrm{~mol} . \mathrm{L}^{-1} \mathrm{HCl}$ solution). 

of $\mathrm{Pd}, \mathrm{Pt}$ and $\mathrm{Au}$ ion in solution

\begin{tabular}{|c|c|c|c|c|c|c|c|}
\hline $\begin{array}{l}\text { Identified } \\
\text { Species }\end{array}$ & $\begin{array}{l}\lambda_{1} \\
(\mathrm{~nm})\end{array}$ & $\begin{array}{l}\varepsilon_{1} \\
(\mathrm{~L} /(\mathrm{mol} . \mathrm{cm}))\end{array}$ & $\begin{array}{l}\lambda_{2} \\
(\mathrm{~nm})\end{array}$ & $\begin{array}{l}\mathcal{E}_{2} \\
(\mathrm{~L} /(\mathrm{mol} . \mathrm{cm}))\end{array}$ & $\varepsilon_{1} / \varepsilon_{2}$ & Observed color & Ref. \\
\hline \multirow{2}{*}{$\mathrm{PdCl}_{4}^{2-}$} & 223 & 24339 & 279 & 8113.4 & 3.00 & - & {$[25]$} \\
\hline & 222 & $24650 \pm 499$ & 278 & $8370 \pm 167$ & 2.95 & Yellow clear & This work \\
\hline \multirow[t]{2}{*}{$\operatorname{Pd}(\text { thiourea })_{4}{ }^{2+}$} & - & (1) & - & (1) & - & $\begin{array}{c}\text { Light Yellow (in } \\
\mathrm{HCl} / \mathrm{HNO}_{3} \text { ) }\end{array}$ & [14] \\
\hline & 246 & $30255 \pm 605$ & 300 & $13875 \pm 278$ & 2.04 & Yellow clear & This work \\
\hline \multirow{2}{*}{ thiourea } & 236 & 12023 & - & - & - & Colorless & [48] \\
\hline & 236 & $13150 \pm 263$ & - & - & - & Colorless & This work \\
\hline \multirow{2}{*}{$\mathrm{PtCl}_{6}^{2-}$} & 202 & 49400 & 262 & 24000 & 2.06 & - & [37] \\
\hline & 202 & $91465 \pm 1829^{[b]}$ & 262 & $24930 \pm 499$ & 3.67 & Yellow clear & This work \\
\hline \multirow{2}{*}{$\begin{array}{c}\mathrm{PtCl}_{4}{ }^{2-} \\
\text { (data not shown) }\end{array}$} & 217 & 12102 & - & - & - & - & [38] \\
\hline & 216 & $12560 \pm 251$ & - & - & - & Yellow clear & This work \\
\hline \multirow{2}{*}{$\operatorname{Pt}(\text { thiourea })_{4}{ }^{2+}$} & - & 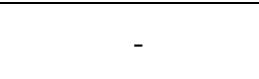 & - & - & - & $\begin{array}{c}\text { Yellow green (in } \\
\mathrm{HCl} / \mathrm{HNO}_{3} \text { ) }\end{array}$ & {$[14]$} \\
\hline & $251^{[\mathrm{c}]}$ & $24915 \pm 498$ & - & - & - & Yellow clear & This work \\
\hline \multirow{2}{*}{$\mathrm{AuCl}_{4}^{-}$} & 226 & - & 311 & - & - & Yellow clear & {$[40,49]$} \\
\hline & 226 & $43780 \pm 876$ & 311 & $7250 \pm 145$ & 6.04 & Yellow clear & This work \\
\hline \multirow{2}{*}{$\mathrm{Au}(\text { thiourea })_{2}^{+}$} & - & - & - & - & - & - & - \\
\hline & 242 & $17610 \pm 352$ & - & - & - & Yellow clear & This work \\
\hline
\end{tabular}

Table 2 - Characterization of untreated leach liquor, as well as leach liquor matrix and analyte recovery fractions after processing on Analig® PM-07 cartridge
Sample nature
A
B
C 1
(filtered sample) (sample matrix from
(first elution fraction)

\begin{tabular}{|c|c|c|c|c|}
\hline \multirow{2}{*}{$\begin{array}{c}\mathrm{HCl} \\
(1 \mathrm{M} \mathrm{HCl})\end{array}$} & $\begin{array}{l}C V \\
\boldsymbol{U} \boldsymbol{V}\end{array}$ & - & - & $\begin{array}{l}X \\
X\end{array}$ \\
\hline & CE & - & - & - \\
\hline \multirow[b]{3}{*}{$\begin{array}{c}\text { HClsp } \\
\text { (Spiked } \mathrm{HCl})\end{array}$} & $C V$ & $+660 \mathrm{mV} /+890 \mathrm{mV}$ & - & $X$ \\
\hline & $U \boldsymbol{V}$ & $263 \mathrm{~nm}$ & $263 \mathrm{~nm}$ & $X$ \\
\hline & $\mathrm{CE}$ & - & - & $\begin{array}{l}{[\mathrm{Pd}]=60.9 \mathrm{mg} / \mathrm{L}} \\
{[\mathrm{Au}]=52.8 \mathrm{mg} / \mathrm{L}}\end{array}$ \\
\hline \multirow{3}{*}{$\begin{array}{c}\mathrm{LL} \\
\text { (Leach liquor) }\end{array}$} & $C V$ & \multicolumn{2}{|c|}{$+785 \pm 10 \mathrm{mV}$} & $X$ \\
\hline & $\boldsymbol{U V}$ & $235 \mathrm{~nm}$ & - & $X$ \\
\hline & CE & - & - & Cu presence \\
\hline \multirow{4}{*}{$\begin{array}{c}\text { LLsp } \\
\text { (Spiked LL) }\end{array}$} & $C V$ & $+630 \mathrm{mV} /+790 \mathrm{mV}$ & $+795 m V$ & $X$ \\
\hline & $\boldsymbol{U V}$ & $263 \mathrm{~nm}$ & $263 \mathrm{~nm}$ & $X$ \\
\hline & $\mathrm{CE}$ & - & - & {$[\mathrm{Au}]=20.6 \mathrm{mg} / \mathrm{L}$} \\
\hline & & & & $\mathrm{Cu}$ presence \\
\hline
\end{tabular}

